\title{
Study of Bioactive Potential of Parahancornia amapa (Huber) Ducke (Apocinaceae) latex collected in Brazilian Amazon
}

\author{
Estudo do Potencial Bioativo de látex amapá Parahancornia amapa (Huber) Ducke \\ (Apocinaceae) coletado na Amazônia Brasileira
}

\author{
A. C. V. Novaes ${ }^{1}$; M. J. U. Toro ${ }^{1}$; J. A. R. Oliveira ${ }^{2}$; D. K. T. Moreira ${ }^{3}$; S. B. \\ Silva ${ }^{4}$; A. S. Lopes ${ }^{4}$; L. H. S. Martins ${ }^{5 *}$ \\ ${ }^{1}$ Department of Food Technology Center for NaturalSciences and Technology State/ Univesity of Pará, 66095-015, \\ Belém, Pará, Brazil. \\ ${ }^{2}$ Faculty of Nutrition/Institute of Health Science, Federal University of Para, 66075-110 Belém, Pará, Brazil. \\ ${ }^{3}$ Department of Food Technology/Federal Institute of Brasília, 72429-005, Brasília, DF, Brazil. \\ ${ }^{4}$ Faculty of Food Engineering/Biotechnological Processes Laboratory, Graduate Program in Food Science and \\ Technology, Federal University of Pará, 66075-110, Belém, Pará, Brazil. \\ ${ }^{5}$ Institute of Animal Health and Production/ Federal Rural University of Amazonia, 66077-830, Belém, Pará, Brazil. \\ *Luiza.martins@ufra.edu.br \\ (Recebido em 09 de fevereiro de 2021; aceito em 21 de junho de 2021)
}

\begin{abstract}
Parahancornia amapa is an Amazonian tree that produces an edible white exudate widely used in folk medicine and food. Studies have found the presence of carbohydrates and bioactive compounds in its composition. The riverside population of the Amazon reports the use of this exudate against respiratory diseases and inflammation. This brief communication aimed to show the bioactive potential of the amapá bitter latex. Samples obtained from four different cities were studied and microbiological, physicochemical, mineral, and bioactive compounds were analyzed (Total Phenolic and antioxidant activity by ORAC and FRAP methods). The results showed relevant physicochemical and mineral composition (Ca, $\mathrm{Mg}$ and $\mathrm{Zn}$ values suggested by the RDA). Furthermore, we found good antioxidant activity throughout latex. The sample from the city of Cametá-PA showed higher values for Total phenolics, and antioxidant activity ORAC and FRAP, respectively. This study is important due to the interesting composition of Parahancornia amapa, which has the potential to be applied in technological routes in the food area.
\end{abstract}

Keywords: antioxidant capacity, bioactive compounds, exudate.

Parahancornia amapa é uma árvore amazônica que produz um exsudato branco comestível amplamente utilizado na medicina popular e na alimentação. Estudos constataram a presença de carboidratos e compostos bioativos em sua composição. A população ribeirinha da Amazônia relata o uso desse exsudato contra doenças respiratórias e inflamações. Esta breve comunicação teve como objetivo mostrar o potencial bioativo do látex amapá amargo. Foram estudadas amostras obtidas de quatro cidades diferentes sendo realizadas análises microbiológicas, físico-químicos, minerais e os compostos bioativos (Fenólico Total e atividade antioxidante pelos métodos ORAC e FRAP). Os resultados mostraram relevante composição físico-química e mineral (valores de $\mathrm{Ca}, \mathrm{Mg}$ e $\mathrm{Zn}$ sugeridos pela RDA). Além disso, encontramos uma boa atividade antioxidante em todo o látex. A amostra da cidade de Cametá-PA apresentou maiores valores para fenólicos Totais, e atividade antioxidante ORAC e FRAP, respectivamente. Este estudo é importante devido à interessante composição da Parahancornia amapa que possui potencial para ser aplicada em rotas tecnológicas na área de alimentos.

Palavras-chave: capacidade antioxidante, compostos bioativos, exsudato.

\section{INTRODUÇÃO}

Plants are related as an important source of the bioactive compounds. The antioxidant potential observed in different parts of the plants (leaves, seeds, exudate, shell) can bring innovating and development to the industry of nutraceutical foods. Vegetable products from the Amazon rainforest are sources of income for approximately one million people in the legal Amazon, representing more than $6 \%$ of the population of this region $[1,2]$.

Parahancornia amapa (Huber) Ducke (Apocinaceae) is an amazonian tree that produces a white edible exudate (latex) widely used in popular medicine. It can be consumed with honey or other foods. Experimental studies have found the presence of acyl-lupeol esters and large amount of 
carbohydrates and phenylethanoids compounds in its composition, as well as pentacyclic triterpenes, such as $\beta$-sitosterol, stigmasterol and $\beta$-sitosterone steroids and its derivatives, that give latex biological activity $[3,4]$.

According to Dimkić et al. (2016) [5], the use of this raw material is very old, in addition to being used as an alternative therapy against diseases of pulmonary origin, it is also used to feed certain native communities in the region These plants have an expressive medicinal value. These extracts produced by the plants, especially the bitter amapá latex (P. amapa) works as a response for the injuries that can occur on the tree trunks (made with or without the aid of people). Such compounds are rich in metabolites that could help to protect the trunk, due to the presence of certain compounds (such as alkaloids, phenolic and terpenes), and also because some institutions as the World Health Organization (WHO) attributes the importance of studies of medicinal plants for the isolation of important substances that contribute to human health.

In Brazil there are a multitude of plants with medicinal properties, since, the country covers a great number of vegetal riches. These plants have an expressive medicinal value and therefore, end up assuming a social, biological, and cultural significance for the regions of their origin [6].

Amapá latex is extracted from two species and has 2 types: sweet amapá latex (Brosimum parinarioides spp. parinarioides Ducke), and bitter amapá latex (Parahancornia amapa). These products are used in the feeding of native population and in popular medicine, since both species (sweet and bitter) show pharmacological properties due to the presence of coumarins and other bioactive compounds [7].

The consumption of forest foods was researched as source of new ingredient and bioactive compound [8]. Amapá latex is one of the most important forest products sold in open markets, herbalists and pharmacies, in cities such as Belém, Igarapé-Miri, Abaetetuba and Barcarena. The municipalities of Ponta de Pedras and Portel, cities located in the Marajó archipelago, supply the consumer market for amapá latex in the city of Belém-PA [9]. In order to evaluate the importance of the latex of amapá in the riverside communities it is necessary to have a more detailed study about this raw material, since the bitter amapá latex presents high bioactive potential. Thus, the present work aimed to carry out physical-chemical, microbiological and antioxidant analyzes of the exudate to verify its potential bioactive capacity, which showed as an interesting alternative in the diet of the population from the Northern region of Brazil.

\section{MATERIAL AND METHODS}

\subsection{Reagents}

Gallic acid ( $\geq 98.0 \%$ ), Folin-Ciocalteau reagent ( $\geq 98.0 \%$ ), Trolox $\left(\mathrm{C}_{14} \mathrm{H}_{18} \mathrm{O}_{4}\right), 2,4,6$-Tris $(2$ pyridyl)-s-triazine T1253 ( $\geq 98.0 \%)$ and DPPH (2, 2-diphenyl-1-picryl-hydrazil) ( $\geq 99.0 \%)$ were acquired from Sigma-Aldrich Brazil Ltda. (São Paulo, Brazil). $\mathrm{Na}_{2} \mathrm{CO}_{3}, \mathrm{FeCl}_{3}$ and methanol solvents ( $\geq 99.0 \%$ ), acetone ( $\geq 99.0 \%$ ), ethyl alcohol ( $\geq 98.0 \%)$, acetic acid ( $\geq 99.0 \%)$, were acquired from Dinâmica Química Contemporânea Ltda. (Recreio Campestre Jóia, Indaiatuba, SP, Brazil).

\subsection{Sample collection and preparation}

The raw materials were purchased in free markets of four municipalities in the state of Pará,

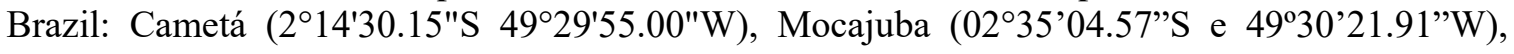

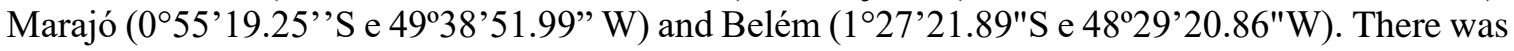
the monitoring the collection process of the amapá latex in all locations. Samples were conditioned in glass bottles, after they were transferred to $100 \mathrm{~mL}$ polyethylene packages hermetically sealed. All samples were maintained at refrigeration temperature $\left(4^{\circ} \mathrm{C}\right)$ until they were analyzed. Figure 1 shows the appearence of the amapá latex used in the present work.

The collection of all samples was within the terms of art. 41 of Decree $n^{\circ} 8.772 / 2016$, that the register of access to genetic heritage or associated traditional knowledge, identified by A1D98C4. 


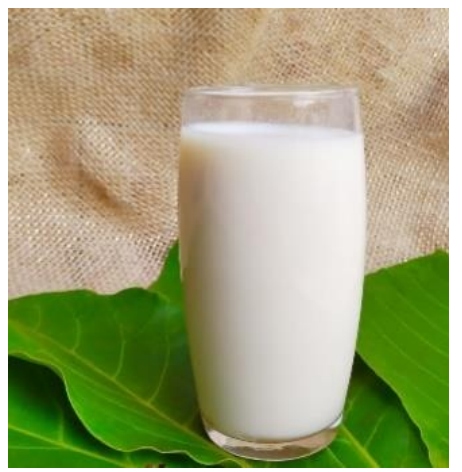

Figure 1: Appearance of amapá latex.

\subsection{Microbiological analysis}

Microbiological analyzes were performed according the da Silva et al. (2018) [10], to filamentous fungi and yeasts (CFU/g), Bacillus cereus (CFU/g), mesophyll aerobes and thermotolerant coliforms [11] and Salmonella spp. governed by ISO 6579 [11].

\subsection{Physical-chemical Analysis}

The physical-chemical analysis was carried out following the method of Adolf Lutz [12] Samples were analyzed in triplicate, the performed determinations were $\mathrm{pH}$, total titratable acidity (TTA), moisture, ash, density, soluble solids ( ${ }^{\circ} \mathrm{Brix}$ ), fixed mineral residue, and proteins (nitrogen conversion factor used was 0.6).

For the quantification of total reducing sugars (TRS), the 3.5 dinitrosalicylic acid (DNS) methodology was used, as described by Maldonade et al. (2013) [13]. Moreover, fat was measured by the method described by Bligh and Dyer (1959) [14]. The total carbohydrate content was calculated according to Resolution RDC 360/2003, by weight difference (100 g - total grams of moisture, proteins, lipids and ashes). The total energy value (TEV) was calculated through amounts of proteins, carbohydrates and lipids, according to the resolution RDC 360/03 food labels [15].

\subsection{Mineralogical analysis}

The micronutrient ( $\mathrm{Fe}, \mathrm{Zn}, \mathrm{Cu}$, and $\mathrm{Mn}$ ) and macronutrient $(\mathrm{N}, \mathrm{P}, \mathrm{K}, \mathrm{Na}, \mathrm{Ca}$, and $\mathrm{Mg}$ ) analyzes of the bitter amapá latex were carried out, according to the methodology of Soares et al. (2004) [16]. Samples of amapá latex were submitted to a digestion system (in the sample digestion, nitric acid, and perchloric acid were used, in the proportion of 3:1), Followed by the digestion phase, Calcium $(\mathrm{Ca})$, magnesium $(\mathrm{Mg})$, iron $(\mathrm{Fe})$, zinc $(\mathrm{Zn})$, copper $(\mathrm{Cu})$ and manganese $(\mathrm{Mn})$, were determined by microwave plasma atomic emission spectrometry (MP-AES - Agilent Technologies - 4200). In the case of sodium ( $\mathrm{Na}$ ) and potassium $(\mathrm{K})$, they were quantified by flame photometry (Quimis - Q498M2), while phosphorus (P), by spectrophotometry, with vanadate yellow (Biospectro - SP - 220).

\subsection{Analysis of phenolic compounds and antioxidant activity (DPPH, ABTS, FRAP and ORAC)}

To the extracts preparation, sample was weighed $(\mathrm{g})$ in test tubes and extracted sequentially with $40 \mathrm{~mL}$ of methanol/water $(50: 50, \mathrm{v} / \mathrm{v})$ at room temperature for $1 \mathrm{~h}$. The tubes were centrifuged at $1,120 \mathrm{G}$ for $20 \mathrm{~min}$ and the supernatant was recovered. Then, $40 \mathrm{~mL}$ of acetone/water $(70: 30, \mathrm{v} / \mathrm{v})$ was added to the residue and extracted for $1 \mathrm{~h}$, after that both were centrifuged. The extracts of methanol and acetone were combined, filtered using Whatman filter paper No. 6, made up to 100 
$\mathrm{mL}$ with distilled water and used to determine the analyzes described below. All samples were analyzed for phenolic compounds and antioxidant activity through FRAP and ORAC pathways.

The content of phenolic compounds was determined by the Folin-Ciocalteu method [17]. The results were calculated from an analytical curve of gallic acid and the result expressed in micrograms equivalent/ milligram sample $\left(\mathrm{GAE} \cdot \mathrm{mg}^{-1}\right)$.

The Ferric Reducing Antioxidant Power (FRAP) assay [18] is related to the ability of polyphenols to reduce $\mathrm{Fe}^{3+}$ to $\mathrm{Fe}^{2+}$. Samples were incubated at $37^{\circ} \mathrm{C}$ and absorbance were detected at $593 \mathrm{~nm}$. The antioxidant capacity was calculated from an analytical curve of Trolox and expressed in $\mu \mathrm{mol}$ equivalent $/ \mathrm{mL}$ sample (TE. $\mathrm{mL}^{-1}$ ).

ORAC analysis was determined according to the protocol of Cao et al. (1993) [19]. The samples were incubated at $37^{\circ} \mathrm{C}$ and fluorescence from the extracts was detected at the wavelengths of 485 $\mathrm{nm}$ (excitation) and $520 \mathrm{~nm}$ (emission). The antioxidant capacity was calculated from an analytical curve of Trolox and expressed in $\mu \mathrm{mol}$ equivalent $/ \mathrm{mL}$ sample (TE. $\left.\mathrm{mL}^{-1}\right)$.

\subsection{Statistical Analysis}

The results of the analysis of composition and bioactive compounds of the bitter amapá latex, together with the physical-chemical, mineralogical and microbiological analyzes were submitted to analysis of variance (ANOVA) and the calculations of the averages by the Tukey test at 5\% probability with the aid of the statistical software Past [20].

\section{RESULTS AND DISCUSSION}

\subsection{Microbiological analysis}

Table 1 shows the microbiological tests for the different samples of latex from amapá. From these results, it is possible to identify the absence of aerobic mesophilic microorganisms, total and thermotolerant coliforms, Bacillus cereus and Salmonella spp., however, there was the presence of filamentous fungi and yeasts.

Table 1: Microbiological analysis for latex from amapá collected in different cities in the State of Pará.

\begin{tabular}{lllll}
\hline Determination & Cametá & Belém & Mocajuba & Marajó \\
\hline Total mesophilic aerobic count (UFC/g) & Absent & Absent & Absent & Absent \\
Total and thermotolerant coliforms (UFC/g) & Absent & Absent & Absent & Absent \\
Filamentous fungi and yeasts (UFC/g) & $2.5 \times 10^{5}$ & $1.7 \times 10^{5}$ & $2.33 \times 10^{4}$ & $2.5 \times 10^{5}$ \\
Bacillus cereus $(\mathrm{UFC} / \mathrm{g})$ & Absent & Absent & Absent & Absent \\
Salmonella spp. (UFC/g) & Absent & Absent & Absent & Absent \\
\hline
\end{tabular}

The extraction of latex is conducted in a rudimentary way where the collectors themselves have no notion of hygiene with the utensils used to make the cracks in the trees, which increases the chances of contamination of the raw material. According to Hobbs and Roberts (1999) [21], the importance of personal and instrumental hygiene awareness must be obeyed and from these standards, one can arrive at the almost total inhibition or absence of microorganisms that cause the degradation of food.

In relation to the frequency of filamentous fungi found in this research, this may be related to the sensitivity of the method used and the quantity of microorganisms present at the time of collection. As for the absence of bacterial isolation, it can be inferred that latex $\mathrm{pH}$ is a limiting 
factor for the growth of these microorganisms, since they develop at a $\mathrm{pH}$ close to neutrality, while fungi develop at $\mathrm{pH} 5.6$ [21].

There is also a need for legislation for this product, it does not have any certification for its quality control.

\subsection{Physical-chemical analysis}

The results of the physical-chemical analyzes (wet basis) carried out for the bitter amapá latex collected in different cities in the state of Pará are shown in Table 2. Samples had a high moisture content, which affects the amounts of soluble solids, and within this fact, we can see a low sugar content that constitute these samples. Free water that is not combined with intrinsic food molecules is automatically available for the processes of chemical reactions, microbiological growth, and enzymatic reactions.

Table 2: Physical-chemical analysis of amapá latex from different cities in the State of Pará.

\begin{tabular}{lcccc}
\hline Determination & Cametá & Mocajuba & Belém & Marajó \\
\hline Density $\left(\mathrm{g} / \mathrm{cm}^{3}\right)$ & $1.01 \pm 0.00^{\mathrm{a}}$ & $0.99 \pm 0.00^{\mathrm{a}}$ & $0.46 \pm 0.00^{\mathrm{b}}$ & $0.74 \pm 0.00^{\mathrm{c}}$ \\
SST (Brix) & $1.00 \pm 0.00^{\mathrm{a}}$ & $2.00 \pm 0.00^{\mathrm{b}}$ & $1.20 \pm 0.00^{\mathrm{b}}$ & $1.60 \pm 0.00^{\mathrm{b}}$ \\
Moisture (g/100g) & $89.00 \pm 0.01^{\mathrm{a}}$ & $90.00 \pm 0.01^{\mathrm{a}}$ & $92.00 \pm 0.00^{\mathrm{a}}$ & $91.00 \pm 0.01^{\mathrm{a}}$ \\
Ashes $(\mathrm{g} / 100 \mathrm{~g})$ & $0.14 \pm 0.014^{\mathrm{a}}$ & $0.17 \pm 0.00^{\mathrm{b}}$ & $0.27 \pm 0.028^{\mathrm{c}}$ & $0.30 \pm 0.00^{\mathrm{d}}$ \\
pH & $2.48 \pm 0.07^{\mathrm{a}}$ & $3.98 \pm 0.02^{\mathrm{b}}$ & $4.18 \pm 0.05^{\mathrm{c}}$ & $4.50 \pm 0.11^{\mathrm{d}}$ \\
Lipids $(\mathrm{g} / 100 \mathrm{~g})$ & $4.37 \pm 0.11^{\mathrm{a}}$ & $1.31 \pm 0.10^{\mathrm{b}}$ & $0.8 \pm 0.05^{\mathrm{c}}$ & $2.77 \pm 0.25^{\mathrm{d}}$ \\
TRS (g/100g) & $1.83 \pm 0.05^{\mathrm{a}}$ & $5.01 \pm 0.34^{\mathrm{b}}$ & $1.69 \pm 0.09^{\mathrm{c}}$ & $4.58 \pm 0.05^{\mathrm{d}}$ \\
Proteins $(\mathrm{g} / 100 \mathrm{~g})$ & $2.41 \pm 0.14^{\mathrm{a}}$ & $1.40 \pm 0.02^{\mathrm{b}}$ & $0.61 \pm 0.13^{\mathrm{c}}$ & $0.51 \pm 0.14^{\mathrm{c}}$ \\
Carbohydrates $(\mathrm{g} / 100 \mathrm{~g})$ & 4.08 & 7.12 & 6.32 & 5.42 \\
TEV (kcal) & 65.29 & 46.51 & 34.92 & 49.83 \\
\hline
\end{tabular}

TTA - Total Titratable Acidity; TSS - Total Soluble Solids, TRS -Total Reducing Sugars TEV = total energy value.

Same letters on the same line do not differ significantly by Tukey test ( $p>0.05)$.

The amount of total soluble solids (Brix) that the samples presented provides almost insignificant values. The content of TSS (Brix) is a relevant factor, because the higher the value of this parameter, the sweeter the food is, presenting a considerable carbohydrate source, as well as an energy source for the metabolic processes for the organism [22]. The latex collected in Mocajuba and Marajó obtained the highest content of ${ }^{\circ}$ Brix and therefore higher amounts of reducing sugars in relation to the others.

Regarding the content of lipids, we can identify a much-diversified content of lipid matter, varying from $0.8-4.37 \%$ among the studied samples.

TTA and $\mathrm{pH}$ analyzes are extremely important, as they can assist in the control of microorganism growth and protein precipitation. Its identification can be based on the parameters of qualities and conservation of the material exposed in study. The sample referring to the city of Cametá, presented the lowest $\mathrm{pH}$ in relation to the others.

It is worth mentioning that there are few works in the literature about bitter amapá latex, there are only reports of the species of latex from sweet amapá (Brosimum parinarioides) mentioned by the authors $[2,23]$. The first author found moisture values from 54.85 to 63.32 ; ash from 0.40 to $0.44 \%$; $\mathrm{pH}$ from 5.37 to 5.42 ; 0.8 to $0.10 \%$ for ATT; 23.33 to $26.03^{\circ}$ Brix. In addition, the second 
author found moisture components of $54.99 \%$, lipids of $34.64 \%$, proteins of $2.14 \%$, carbohydrates of $5.72 \%$, ash of $2.41 \%$, fibers of $2.04 \%$ and energy of $343.2 \mathrm{kcal}$.

According to Palheta et al. (2015) [2], the nutritional characteristics of sweet amapá latex show that it is an energetic food, which probably justifies its use as a milk substitute when added for breakfast by the Amazonian population from the Northern of Brazil.

If we compare the composition of amapá latex with commonly consumed bovine milk, we can see that there is an interesting physicochemical composition, since the composition of cattle milk is composed on average of $4.14 \%$ fat, $3.62 \%$ of proteins, $13.53 \%$ of Brix [25], thus, the consumption of amapá latex to replace bovine milk, presents itself as a product with low fat content and high content of bioactive compounds.

Galuppo (2004) [24] carried out the physical and chemical tests were also carried out to assess the nutritional value of amapá latex when compared to compared to cow's milk and soy extract (soy "milk"), all related to the recommended daily dose. As a result, the sweet amapá latex had 58\% moisture and a good amount of some minerals in its composition. It should also be emphasized that factors such as soil nutrition, climate and geographical differences can cause differences in the composition of vegetables [24].

\subsection{Mineralogical analysis}

Table 3 shows the results of macro and micronutrients from latex samples from different cities in Pará. The analysis of minerals was carried out in order to determine the main elements contained in the samples and which may be necessary for human nutrition, based on RDC resolution No. 269, of September 22, 2005 DOU 9/23/05 [26] on Recommended Dietary Allowance (RDA) for each inorganic factor.

Table 3: Mineralogical analysis of the bitter amapá latex from different cities in the state of Pará.

\begin{tabular}{lcccc}
\hline Mineral & \multicolumn{3}{c}{ Samples } \\
\hline $\mathbf{N}(\mathbf{g} / \mathbf{k g})$ & $3.87 \pm 0.24^{\mathrm{a}}$ & $2.25 \pm 0.04^{\mathrm{b}}$ & $1.00 \pm 0.00^{\mathrm{c}}$ & $1.07 \pm 0.10^{\mathrm{c}}$ \\
$\mathbf{P}(\mathbf{g} / \mathbf{k g})$ & $\mathrm{ND}$ & $0.15 \pm 0.01^{\mathrm{b}}$ & $0.14 \pm 0.00^{\mathrm{b}}$ & $0.14 \pm 0.01^{\mathrm{b}}$ \\
$\mathbf{K}(\mathbf{g} / \mathbf{k g})$ & $0.21 \pm 0.07^{\mathrm{a}}$ & $0.09 \pm 0.00^{\mathrm{b}}$ & $0.01 \pm 0.00^{\mathrm{b}}$ & $0.08 \pm 0.00^{\mathrm{b}}$ \\
$\mathbf{N a}(\mathbf{g} / \mathbf{k g})$ & $0.10 \pm 0.00^{\mathrm{a}}$ & $2.04 \pm 0.01^{\mathrm{b}}$ & $0.94 \pm 0.02^{\mathrm{c}}$ & $0.98 \pm 0.04^{\mathrm{c}}$ \\
$\mathbf{C a}(\mathbf{g} / \mathbf{k g})$ & $0.11 \pm 0.00^{\mathrm{a}}$ & $0.71 \pm 0.01^{\mathrm{b}}$ & $0.65 \pm 0.00^{\mathrm{c}}$ & $0.78 \pm 0.00^{\mathrm{b}}$ \\
$\mathbf{M g}(\mathbf{g} / \mathbf{k g})$ & $0.03 \pm 0.00^{\mathrm{a}}$ & $0.11 \pm 0.01^{\mathrm{b}}$ & $0.10 \pm 0.00^{\mathrm{b}}$ & $0.12 \pm 0.00^{\mathrm{b}}$ \\
$\mathbf{F e}(\mathbf{m g} / \mathbf{k g})$ & $3.03 \pm 0.20^{\mathrm{a}}$ & $21.49 \pm 0.38^{\mathrm{b}}$ & $6.83 \pm 0.08^{\mathrm{c}}$ & $9.48 \pm 0.10^{\mathrm{d}}$ \\
$\mathbf{Z n}(\mathbf{m g} / \mathbf{k g})$ & $6.19 \pm 0.19^{\mathrm{a}}$ & $3.75 \pm 0.33^{\mathrm{b}}$ & $5.96 \pm 0.45^{\mathrm{a}}$ & $3.45 \pm 0.46^{\mathrm{b}}$ \\
$\mathbf{C u}(\mathbf{m g} / \mathbf{k g})$ & $1.11 \pm 0.03^{\mathrm{a}}$ & $1.67 \pm 0.12^{\mathrm{b}}$ & $1.61 \pm 0.15^{\mathrm{b}}$ & $1.55 \pm 0.14^{\mathrm{b}}$ \\
$\mathbf{M n}(\mathbf{m g} / \mathbf{k g})$ & $0.71 \pm 0.02^{\mathrm{a}}$ & $0.68 \pm 0.02^{\mathrm{a}}$ & $0.58 \pm 0.01^{\mathrm{b}}$ & $0.86 \pm 0.01^{\mathrm{c}}$ \\
\hline
\end{tabular}

ND $=$ Non detected.

Same letters on the same line do not differ significantly in the Tukey test ( $p>0.05)$.

The samples from Marajó, Mocajuba and Belém showed a calcium profile very close to that suggested by the RDA $(1 \mathrm{~g} / \mathrm{Kg})$. Therefore, the calcium in the bitter amapá latex can be an important source in the combat of bone diseases, hypocalcemia and women in the menopause period 9].

The amount of $\mathrm{Mg}$ in the sample exceeds the amount required by daily intake $(0.26 \mathrm{~g} / \mathrm{kg})$ for this element. The samples have a good profile of this mineral, therefore. According to Fiorini (2008) [27], magnesium has several functions when metabolized and absorbed in the body, one of the most 
important is that this compound is able to regulate more than 300 enzymatic reactions that occur constantly in human beings.

The "Zn" zinc was also found in considerable quantities in the samples of bitter amapá latex, considering the daily intake $(0.7 \mathrm{~g} / \mathrm{kg})$ as a reference, it can be highlighted that this raw material is a source of this mineral.

Fiorini (2008) [27] points out the $\mathrm{Zn}$ present in food has an action in over 100 enzymes so that reactions present in the body occur, and a portion of those enzymes assisting with an enzymatic cofactor in the synthesis and degradation of macromolecules. The same author highlights those foods of plant origin have factors that can inhibit the absorption of this element in the body, factors such as tannins, alcohol, fibres, antibiotics, and oral contraceptives. The lack of this component brings delayed sexual development, body development and deficiency in immunity.

Therefore, it can be observed that bitter amapá latex has truly relevant mineralogical properties in comparison to other foods and values awfully close to IDR making it a food with mineralogical potential.

\subsection{Phenolic compounds and antioxidant activity}

The amapá latex is a natural plant polymer containing a complex mixture of secondary metabolites, including phenolic compounds, secreted by laticiferous cells and exudated by various parts of the plant after suffering a minor tissue injury [28]. The total phenolic content of amapá latex from Belém, Marajó, Cametá and Mocajuba was $127.92 \pm 4.89 ; 127.92 \pm 10.74 ; 192.01 \pm$ 13.43 and $121.04 \pm 9.51 \mu \mathrm{g}$ GAE.mL ${ }^{-1}$ latex, respectively. Among the different locations, sample from Cametá had a significantly higher TP content $(\mathrm{p}<0.05)$ than the other samples (Figure 2$)$.
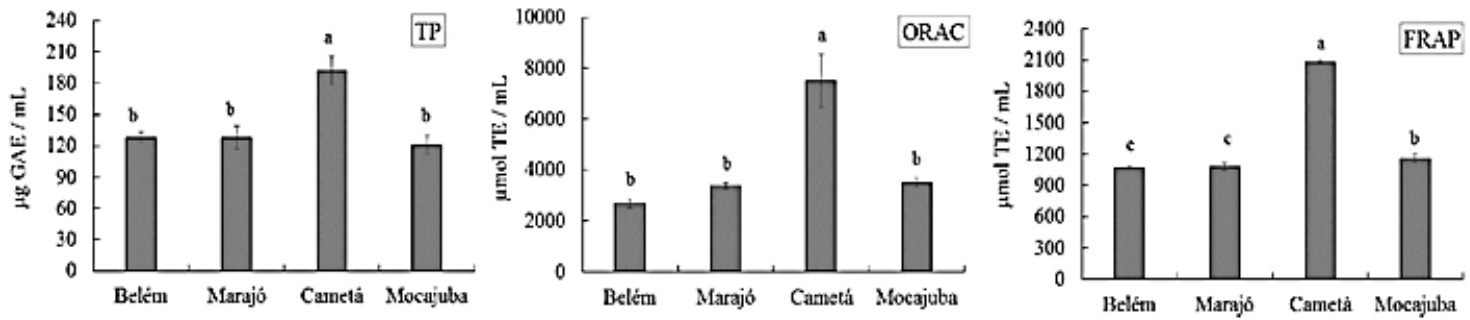

Figure 2: Analysis of phenolic total (TP) e antioxidant activity (ORAC and FRAP) of bitter amapá latex. Samples with their respective means of three replicates, standard deviation and equal letters on the same line do not differ significantly in the Tukey test ( $p>0.05)$.

All amapá latex samples showed antioxidant activity against the peroxyl radical and by the reduction of the iron ion. The sample obtained from the municipality of Belém had the highest PT content and, consequently, the best antioxidant activity compared to the ORAC and FRAP method, when compared with the other samples. Regarding the types of tests to assess antioxidant capacity (Figure 2), samples showed greater activity in the ORAC method than in the FRAP method. This supposes that the compounds present in the latex showed a greater transfer of hydrogen atoms than electrons, having a good competition in relation to the peroxyl radical generated in the test [29]. These results are highlighted by the correlation of phenolic compounds with the methods of determining antioxidant capacity, presenting a positive and significant correlation $(p<0.05)$ for all methods, being stronger for FRAP $(r=0.938)$ than for the ORAC method $(r=0.885)$. Therefore, amapá milk has a potential to play an action in the prevention of oxidative stress, identified as the cause of some diseases, such as arteriosclerosis, diabetes and neurodegenerative diseases [29].

It is important to note that amapá latex showed good mineral composition (Table 3), and this can be interesting when associated with its bioactive compounds. Mistry and Williams (2011) [30], pointed that mineral content can influence the antioxidant capacity of foods, among which stand out, zinc (helps in the absorption of fat-soluble vitamins and it is an important cofactor for the superoxide dismutase enzyme, which participates in reactions against free radicals), copper 
(participates in the synthesis of proteins that can bind to metals, such as copper, preventing the formation of free radicals) and magnesium (the deficiency of this mineral is related to the increase in lipid peroxidation, inflammatory response and decrease of the antioxidant action).

Galuppo (2004) [25] evidenced the presence of the following compounds in the tested fractions of lyophilized amapá latex (Brosimum parinarioides), such as alkaloids, anthraquinones, coumarin derivatives, steroids and triterpenoids, and purines.

Regarding antioxidant activity, research shows that they are related to amounts of tannins and flavonoids present in sweet amapá latex (Brosimum parinarioides DUCKE), together with biological activity (antioxidant and antimicrobial). Several authors claim that the beneficial properties of these antioxidants are related to their ability to scavenge free radicals, the molecules responsible for aging in humans [23].

\section{CONCLUSION}

Samples of bitter amapá latex analyzed from different cities in Brazilian Amazon showed relevant antioxidant activity. The city of Cametá-PA showed the raw material that stood out in relation to the ones from others studied cities. Even though Cametá showed higher bioactive compounds concentration in relation to the samples from other cities (that was well elucidated by Tukey analysis), all of them presented the bioactive potential to be applied in the chemical, pharmaceutical, and food industries. The study of the composition and antioxidant activity of the bitter amapá latex sample is an important data in the literature because it has a great nutraceutical potential composition. However, a toxicological analysis must be carried out on this raw material to consolidate its use as food for the human population.

\section{ACKNOWLEDGMENT}

The authors acknowledge UEPA (Universidade do Estado do Pará) and UFRA (Universidade Federal Rural da Amazônia) for space to the development, scientific research, and all support. The authors also acknowledge Msc. Amanda Gatinho Teixeira for her valuable collaboration with the art and photography of amapá latex used in this research.

\section{REFERENCES}

1. Nogueira JM, Junior AN, Bastos, L. Empreendimentos extrativistas como alternativas para geração de renda: do sonho ambientalista à realidade do estudo de mercado. Rev Ciências Administrativas. 2009;15(1):85-104, doi: 10.5020/2318-0722.15.1.\%25p.

2. Palheta RA, da Cruz Filho RF, Carneiro ALB, Teixeira MFS. Composição nutricional e controle de qualidade do leite de amapá doce (Brosimum parinarioides DUCKE). Bol Centro Pesq Processamento Alimentos. 2015;33(2):1-8, doi: 10.5380/cep.v33i2.47166.

3. Carvalho MGD, Velloso CRX, Braz-Filho R, Costa WFD. Acyl-lupeol esters from Parahancornia amapa (Apocynaceae). J Braz Chem Soc. 2001 Jul;12(4):556-9, doi: 10.1590/S0103-50532001000400020.

4. Lopes MBP, Mendonça PM, Mallet JRS, Carvalho MG, Queiroz MMC. Bioactivity of the latex from Parahancornia amapa (Apocynaceae) on the development of Rhodnius nasutus (Hemiptera, Reduviidae, Triatominae) under laboratory conditions. Rev Bras Entomol, 2014 Sep;58(4):379-83, doi: 10.1590/S0085-56262014005000001.

5. Dimkić I, Ristivojević P, Janakiev T, Berić T, Trifković J, Milojković-Opsenica D, Stanković S. Phenolic profiles and antimicrobial activity of various plant resins as potential botanical sources of Serbian propolis. Ind Crop Prod. 2016 Dec;94:856-71, doi: 10.1016/j.indcrop.2016.09.065.

6. Veiga Junior VF, Pinto AC, Maciel MAM. Plantas medicinais: cura segura? Quím Nova. 2005;28(3):51928, doi: 10.1590/S0100-40422005000300026.

7. Shanley P, Medina G, Cordeiro S, Imbiriba M. Frutíferas e plantas úteis na vida amazônica. Belém (AM): CIFOR, Imazon; 2005. $310 \mathrm{p}$.

8. Gelatti G, Oliveira K, Colet C. Potenciais interações relacionadas ao uso de medicamentos, plantas medicinais e fitoterápicos em mulheres no período do climatério. Rev Pesquisa: Cuidado é Fundamental. 2016 Apr;8(2):4328-46, doi: 10.9789/2175-5361.2016.v8i2.4328-4346. 
9. Sousa RL, Costa JFS, Costa JM, Pereira MGS, Cordeiro YEM. Etnobotânica de Parahancornia fasciculata (Apocynaceae): extração, usos e comercialização do leite de amapá na comunidade da ilha Trambioca, Barcarena, Pará, Brasil. Sci Plena. 2019;15(11):1-8, doi:10.14808/sci.plena.2019.112701.

10. da Silva N, Taniwaki MH, Junqueira VCA, Silveira N, Okazaki MM, Gomes RAR. Microbiological examination methods of food and water: A laboratory manual. London (GB): CRC Press; 2018. 564 p.

11. International Standart Organization. ISO6579-1:2017: Microbiology of food and feed - Horizontal method of detection of Salmonella spp. Switzerland: ISO; 2017. 50 p.

12. IAL. Métodos físico-químicos para análise de alimentos. São Paulo: Instituto Adolfo Lutz; 2008.1020 p.

13. Maldonade IR, Carvalho PGBd, Ferreira NA. Protocolo para determinação de açúcares totais em hortaliças pelo método de DNS. Brasília (DF): Embrapa Hortaliças; 2013. (Comunicado Técnico; 85).

14. Bligh EG, Dyer WJ. A rapid method of total lipid extraction and purification. Can J Biochem Physiol. 1959 Aug;37(8):911-7. doi: 10.1139/o59-099.

15. Brasil, Ministério da Agricultura, Pecuária e Abastecimento. Instrução Normativa $n^{\circ} 22$, de 24 de novembro de 2005. Diário Oficial da União. 25 nov 2005;226(Seção 1):15-6. Anexo, Regulamento Técnico para Rotulagem de produto de origem animal embalado; p. 15-6.

16. Soares LMV, Shishido K, Moraes AMM, Moreira VA. Composição mineral de sucos concentrados de frutas brasileiras. Food Sci Technol. 2004;24(2):202-6, doi: 10.1590/S0101-20612004000200007.

17. Singleton VL, Rossi JA. Colorimetry of total phenolics with phosphomolybdic-phosphotungstic acid reagents. Am J Enology Viticulture. 1965;16(3):144-58.

18. Benzie IFF, Strain JJ. The ferric reducing ability of plasma (FRAP) as a measure of "antioxidant power": the FRAP assay. Anal biochem. 1996;239(1):70-6, doi: 10.1006/abio.1996.0292.

19. Cao G, Alessio HM, Cutler RG. Oxygen-radical absorbance capacity assay for antioxidants. Free Radic Biol Med. 1993 Mar;14(3):303-11, doi: 10.1016/0891-5849(93)90027-r.

20. Hammer O, Harper D, Ryan P. PAST: Paleontological statistics software package for education and data analysis. Palaeont Electronica. 2001;4:1-9.

21. Hobbs BC, Roberts D. Toxinfecções e controle higiênico-sanitário de alimentos. São Paulo: Livraria Varela; 1999. 425 p.

22. Karmas E, Harris RS. Nutritional evaluation of food processing. Netherlands: Springer Science \& Business Media; 2015. 786 p.

23. Yano CY, Mattietto RA, Cordeiro B S. Caracterização físico-química do látex do amapá-doce proveniente do município de Moju, Pará. In: Anais da 59ª Reunião Anual da SBPC. Brasília (DF): Embrapa Amazônia Oriental; 2007.

24. Galuppo, SC. Documentação do uso e valorização do óleo de piquiá (caryocar villosum (aubl) pers.) e do leite do amapá-doce (Brosimum parinarioides ducke) para a comunidade de piquiatuba floresta nacional do tapajós. estudos físicos, químicos, fitoquímicos e farmacológicos [master's dissertation]. Belém (PA): Universidade Federal Rural da Amazônia; 2004. 92 p.

25. Galvão Júnior JGB, Rangel AHN, de Medeiros HR, da Silva JBA, de Aguiar EM, Madruga RC, de Lima Júnior DM. Efeito da produção diária e da ordem de parto na composição físico-química do leite de vacas de raças zebuínas. Acta Veterinaria Bras. 2010;4(1):25-30.

26. Brasil, Agência Nacional de Vigilância Sanitária. Resolução RDC no 269, de 22 de setembro de 2005. Diário Oficinal da União. 23 nov 2005;184(Seção 1):372. Anexo, Regulamento técnico sobre a ingestão diária recomendada (IDR) de proteína, vitaminas e minerais; p. 372.

27. Fiorini LS. Dossiê: Os minerais na alimentação. Rev Food Ingredients Brasil. 2008;(4):48-59.

28. Bezerra VS, Mattietto RDA, Coelho EAA, Aguiar, FFD. Pasteurização do leite-do-amapá in natura para controle do escurecimento enzimático. Ciência Rural. 2013;43(9):1715-20, doi: 10.1590/S010384782013000900028

29. Asadi S, Ahmadiani A, Esmaeili MA, Sonboli A, Ansari N, Khodagholi F. In vitro antioxidant activities and an investigation of neuroprotection by six Salvia species from Iran: A comparative study. Food Chem Toxicol. 2010 May;48(5):1341-9, doi: 10.1016/j.fct.2010.02.035.

30. Mistry HD, Williams PJ. The importance of antioxidant micronutrients in pregnancy. Oxid Med Cell Longev. 2011;2011:841749, doi: 10.1155/2011/841749. 